den vi møder hos Arendt i hendes kristent farvede bestemmelse af natalitet. Godt nok findes der også i liberalismen en understregning af spontaniteten, men her ofte med kræmmeragtige undertoner. At den menneskelige spontanitet hos Arendt får en status som aldrig før set, er sikkert i det mindste medbetinget af hendes erfaring med og blotlæggelse af totalitarisme. Den er nemlig - over alt og $i$ enhver form - spontanitetens absolutte negation.

Arendt skriver godt. I modsætning til hendes lærer (Heidegger) er der få neologismer, og i hvert fald ikke nogen tilstræbt orakelfilosoferen (hendes filosofiske husguder var Augustin, Kant og Heidegger, og hendes yndlingsforfatter - for hun læste litteratur og indbyggede erfaringer herfra i sin politiske filosofi - var Karen Blixen). Til gengæld kan hun være vanskelig at læse. Det kommer af, at hun trækker på en stor tradition og er yderst belæst - også indenfor skønlitteratur. Men det kommer primært af to andre forhold: dels er hendes stil expressionistisk, dels slår hun ofte meget originale ideer an - uden egentlige begrundelser, men nok med iøjnefaldende konsekvensdragninger. Det gælder til eksempel hendes begreb om natalitet. Og ofte er hendes grundbestemmelser af quasimetafysisk art, samtidig med at hun drager empiriske konklusioner. Det gælder f.eks. hendes skelnen mellem arbejde og fremstillen. Og det gælder vel også hendes begreb om politik, som nærmer sig det teatralske.

At der kan rettes en række kritikker mod hendes tænkning er imidlertid ikke et indicium på dennes mangel på originalitet og dybde - snarere tvært imod. Hendes samtidige Isaiah Berlin kaldte hende et tågehorn. En bedre betegnelse ville have været et fyrtårn, for hun rager virkelig op og kaster lys - få så være, at der ved foden af dette tårn kan være mørke.

Hans-Jorgen Schan₹

\section{Estetisk revolution}

Morten Haugaard Jeppesen: Den cestetiske revolution. Forlaget Modtryk, 2005,

Mens 200-året for Friedrich Schillers død i 2005 fejredes overalt i Tyskland, var der i Danmark ikke mange udgivelser eller arrangementer i den anledning. En undtagelse er dog Morten Haugaard Jeppesens (MHJ) Den æstetiske revolution, hvis ærinde det er at vise, hvordan en realisering af friheden i lyset af den franske revolution bliver til et æstetisk projekt i Schillers teoretiske værk, fortrinsvis i brevene om menneskets æstetiske opdragelse.

MHJ behandler Schiller i forlængelse af Kant og bruger derfor halvdelen af bogen på at behandle dels Kants forhold til den franske revolution, dels Kants æstetik. 'Den æstetiske revolution' er en betegnelse taget fra den amerikanske forsker Bernard Yack (som MHJ er inspireret af) og defineres som det, at friheden alene kan realiseres æstetisk. Det er MHJs tese, at den æstetiske revolution er at 
forstå som et svar på den udfordring, den franske revolution stiller. Det er ligeledes hans tese, at denne fordring om en æstetisk revolution først får sin endelige udformning med Schiller.

I bogens første kapitel behandler MHJ Kant og den franske revolution og skaber vha. læsninger af en lang række skrifter et sammenhængende billede af Kants komplicerede forhold til den franske revolution. I kapitel to vil $\mathrm{MHJ}$ undersøge samme forhold til den franske revolution, nu blot Schillers, og påpeger, at Über die ästhetische Erziehung des Menschen in einer Reihe von Briefen er skrevet som en reaktion på den franske revolutions blodige begivenheder. Schillers svar er, ifølge MHJ, at friheden alene lader sig virkeliggøre gennem skønheden. I kapitlet behandler MHJ også kort den litterære del af Schillers forfatterskab. MHJ forsøger via Schillers dramaer at forklare årsagerne til den forfejlede kategorisering af Schiller som 'frafalden revolutionær' og argumenterer i stedet for en kontinuitet i Schillers værk. Til egentlige læsninger af Schillers litterære værk er der dog ikke givet plads.

I bogens anden del, kapitel tre og fire, behandles henholdsvis Kants og Schillers æstetik. MHJ lægger ud med at behandle Kants forsøg på i Kritik der Urteilskraft at forene den splittelse, der er blevet etableret $i$ de to forudgående kritikker. Efter via Hegel, Baumgarten og Leibniz at have dannet et grundlag, ud fra hvilket han kan påvise Kants format, begi- ver MHJ sig ud i en læsning af Kritik der Urteilskraft. Det er spændende læsning, men dog også sprogligt en smule knudret.

I kapitel fire læses Schiller ind i rækken af Kants arvtagere. Hvor Schiller i Kallias oder über die Schönheit beskæftiger sig med at bestemme det skønne som sanseligt-objektivt, er det $i$ Über die ästhetische Erziehung des Menschen in einer Reihe von Briefen forholdet mellem frihed og skønhed, der interesserer ham. I Schillers ofte noget dunkle skrift opstår der imidlertid, hvad der umiddelbart må synes som en modsigelse (og som også anses som sådan af dele af forskningen), for hvordan skal den af Schiller ønskede frihed realiseres? Via æstetik eller til æstetik? For MHJ er der dog ikke tale om en modsigelse, da Schiller allerede i tredje brev har tildelt æstetikken en dobbeltfunktion. Det kunne her have været interessant med en uddybende diskussion af dette stridspunkt (evt. med inddragelse af forskningen), især fordi dette punkt har afgørende betydning for MHJs tese.

I kapitlets afsluttende del, som samtidig udgør bogens afslutning, placerer MHJ Schillers æstetiske utopi som et tredje bud i forhold til fascismens æstetisering af det politiske (Benjamin) og den politiske romantik (Schmitt). Schiller lader sig imidlertid ikke forstå som en egentlig forløber for disse bud, og MHJ vælger derfor at lave en sammenligning med de samtidige skrifter Das älteste Systempro- 
gramm des deutschen Idealismus og Fichtes revolutionsskrift, hvor fællesskabet udgøres af ønsket om det politiskes opløsning i det æstetiske. Schiller står derfor ikke alene, men læses af MHJ som den første, der udkaster den tanke, at friheden alene kan realiseres æstetisk, og at denne realisering har æstetisk karakter, i form af et kunstværk.

Læsningen af Den æstetiske revolution giver anledning til spørgsmålet om, hvem MHJ henvender sig til. Er det populærvidenskab, $\mathrm{MHJ}$ ønsker at bedrive? Dette er næppe tilfældet, for så skulle bogen, der oprindelig var en ph.d-afhandling, have været omskrevet yderligere og de tunge Kant-dele gjort lidt mere spiselige. $\mathrm{MHJ} ø$ nsker at bedrive filosofisk idéhistorie, og som sådan henvender hans bog sig til et akademisk publikum. I forlængelse heraf vækker det forundring, at bogen ikke er forsynet med en litteraturliste, at der næsten kun tages stilling til forskningen $i$ fodnoter, og at der ikke citeres på tysk eller i det mindste henvises til originalbegreberne. Især det sidste punkt skæmmer en ellers overbevisende læsning og udlægning af Kants sidste kritik.

I anledning af Schilleråret kunne man have ønsket, at denne udgivelse havde behandlet Schillers værk og ikke blot Schiller i forlængelse af Kant (selvom kapitlerne om Kant er bogens bedste). Jeg savner også en klarere perspektivering og stillingtagen til forskningen. Bernard Yacks bog The Longing for Total Revolution, hvorfra MHJ har sit begreb 'æstetisk revolution', nævnes flere gange i fodnoterne (og afhængigheden tilkendegives også), men inddrages ikke i en egentlig diskussion. Ligeledes er der i fodnoterne adskillige små fine pointer, og det er næsten en skam, at de ikke er fremhævet i selve teksten.

Den æstetiske revolution er interessant for sin behandling af Kant, men overordnet set lider bogen af manglende klarhed i fokus. Læsningerne af de filosofiske tekster er i sig selv klare nok, men MHJ forsømmer at anskue teksterne fra oven, hvor det er nødvendigt. Dette samt den manglende inddragelse af forskningen gør det svært at få øje på bogens raison d'être, når den behandler en så tiltrampet problemstilling som Kants og Schillers æstetiske teori.

\section{Louise Ebbesen Nielsen}

\section{Et liberalt lys}

Isaiah Berlin: Den ideale straben og andre essays, Gyldendal, 2005, 343 sider, kr. 375 ,-

Der foreligger nu et større tekstudvalg på dansk af den russisk-engelske filosof og idehistoriker - det sidste valgte han selv at kalde sig - Isaiah Berlin (1909-1997). Anders Smith har oversat dygtigt og skrevet en mindre dygtig introduktion, skæmmet af en bunke uvedkommende polemik.

Berlin blev en af det tyvende århundredes store liberale tænkere, hvis 